\title{
Cerebral Hemorrhage
}

National Cancer Institute

\section{Source}

National Cancer Institute. Cerebral Hemorrhage. NCI Thesaurus. Code C50485.

Bleeding within the cerebrum. 